\title{
An Algorithm for Detecting the Center of the Iris Using a Color Image and Improvements of Its Processing Speed
}

\author{
Tetsuya Yonezawa Member (Yatsushiro National College of Technology, yonezawa@as.yatsushiro-nct.ac.jp) \\ Kohichi Ogata Member (Kumamoto University, ogata@eecs.kumamoto-u.ac.jp) \\ Kazuyuki Shiratani Non-member (Kumamoto University)
}

Keywords: color image,filtering in the HSI space,pattern matching, improvement of the pattern matching speed

In this paper, we describe an algorithm for detecting the center of the iris and two procedures in which the processing speed of pattern matching is faster than with the usual procedure. Furthermore, we evaluate the accuracy of the eye gaze detection using 25 points on a 17 -inch display.

Fig.1 shows an algorithm for detecting the center of the iris. The algorithm is made up of three main parts. These parts are: filtering in the HSI space; preprocessing for pattern matching; and detection of the center of the iris using pattern matching.

Fig.2 shows the pattern matching result using a ring shaped template. The detecting region is delineated by a square in which the center of the square is the same as the center of the centroid of the iris. The detecting region is the area in which the center of the standard circle moves within for pattern matching. Pixels of contour of the iris and standard circle are matched within a ringshaped template. The center of the iris is detected as the center of the standard

\begin{tabular}{|c|}
\hline Filtering in the HSI space \\
\hline $\begin{array}{l}\text { Preprocessing for pattern matching } \\
\text { - Reduction of processing area } \\
\text { - Edge detection in the processing area } \\
\text { - Detection of the centroid }\end{array}$ \\
\hline $\begin{array}{l}\text { Detection of the center of the iris } \\
\text { using pattern matching }\end{array}$ \\
\hline
\end{tabular}

Fig. 1. An algorithm for detecting the center of the iris

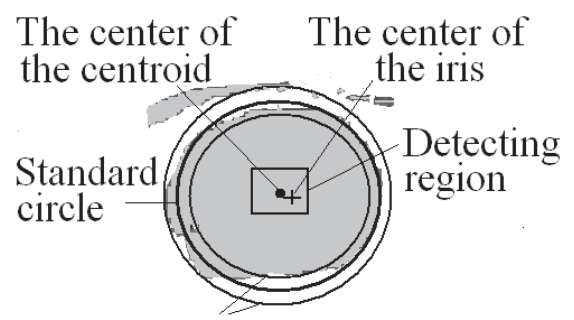

Ringshaped template

Fig. 2. Pattern matching circle after pattern matching.

We propose two procedures to reduce pattern matching calculation costs. The first procedure is to set a smaller detecting region surrounding the center of the centroid of the iris. Therefore, the iteration number of pattern matching is reduced. The second procedure is the coarse-to-fine scanning method. Fig. 3 shows the processing time of pattern matching. The two procedures proposed can reduce the pattern matching calculation costs.

We evaluated the accuracy of the eye gaze detection. Five subjects attended the evaluation experiment. In the experiment, a target was randomly generated at 25 points on a 17-inch display in front of the subject. The center of the iris was detected and the estimated eye gaze on the display was calculated using the proposed method during two seconds for each target point. Because the frame rate of the camera is 30 frames/s, 60 eye images were used for the calculation. Mean values in the horizontal and vertical directions over the subjects and target points are 1.78 and 1.82 degrees, respectively. Standard deviations are 1.43 and 1.46 degrees, respectively.

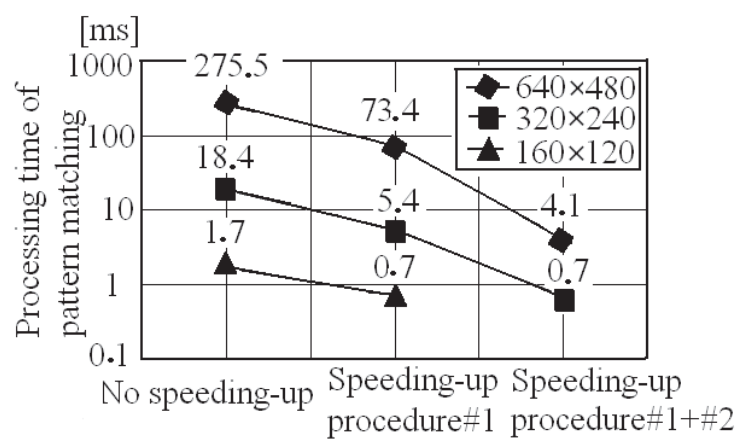

Fig. 3. Processing time of pattern matching 


\title{
カラー画像による虹彩中心検出アルゴリズムとその高速化
}

\author{
正 員 米沢 徹也* 正 員 緒方 公一** \\ 非会員 白谷 和幸**
}

\author{
An Algorithm for Detecting the Center of the Iris Using a Color Image and \\ Improvements of Its Processing Speed
}

Tetsuya Yonezawa*, Member, Kohichi Ogata**, Member, Kazuyuki Shiratani**, Non-member

We have studied a man-machine interface system by using an eye gaze detection technique. Target users for this system are ordinary people and orthopedically impaired people who have no movement in their hands and heads. Ordinary people can use this system under the condition that they do not move their heads. An algorithm for detecting the center of the iris is proposed in this paper. An image of the eye is captured with a small video camera and the center of the iris is obtained by filtering in color space and pattern matching with a ringshaped template. Improvement of the pattern matching speed is also described and the effectiveness of the reduction of calculation costs is shown in the paper. Furthermore, the accuracy of the eye gaze detection was evaluated.

キーワード : カラー画像, 色空間フィルタリング, パターンマッチング, 高速化アルゴリズム

Keywords: color image, filtering in the HSI space, pattern matching, improvement of the pattern matching speed

\section{1. まえがき}

近年, コンピュータ技術の進歩により, 様々な分野でコン ピュータが利用されるようになってきた。ポインティング デバイスとしては，マウスやトラックボールなど多くの装 置が開発されている。特に, 手足が不自由あるいは頭部の 動作が困難な障害者に対してのポインティングデバイスの 開発が望まれている(1)。また，目の動きを測定する様々な 手法が提案されている(2)(3)。このような環境において頭部 や手の動作が困難な重度肢体不自由者のコミュニケーショ ン装置として，ビデオカメラにより捉えた目の動きを用い るシステムが研究されている (4) (7)。これらの装置は, 障害 者だけではなく，健常者が頭部を固定した状態でも用いる ことができる。ディスプレイ上に表示されたメニューやア イコンを視線により選択して，意識的閉眼等によりクリッ ク動作を行い, パソコンを操作する視線入力インタフェー

\footnotetext{
*八代工業高等専門学校

干 866-8501 熊本県八代市平山新町 2627

Department of Information and Electronics Engineering, Yatsushiro National College of Technology

2627 Hirayama-shinmachi, Yatsushiro-shi, Kumamoto 8668501

** 熊本大学大学院自然科学研究科

干 860-8555 熊本市黒髪 2-39-1

Graduate School of Science and Technology, Kumamoto University

2-39-1 Kurokami, Kumamoto-shi, Kumamoto 860-8555
}

スシステムは，ユーザにとってより簡便で高速な使いやす いシステムになるように開発が望まれている。動画像の入 力に関しては従来からのアナログビデオカメラの動画像を 画像入力ボードを通してパソコンに取り込む方法に加え, 近年ではディジタルビデオカメラの開発が進み, USB や IEEE1394のインタフェースを介して, 直接動画像をパソ コンに入力できる環境も整ってきた。入力法の違いはある が, 一旦パソコンに取り込んだ動画像からソフトウェアに より視線検出を高速に行う手法の開発は, 視線入力インタ フェース装置開発における重要な課題であると考えられる。 ビデオカメラを用いた視線検出の研究は, 目に赤外線を 照射して得られた白黒画像を目画像として取り扱っている ものが多い(4)(8)。これらは瞳孔部の反射率が他の部分に比 べ大きいことを利用しており, 瞳孔部の検出に非常に有用 である。しかし, 赤外線は照射を続けると, 目に有害であ るという報告もある ${ }^{(9)}$ 。目のカラー画像を用いて虹彩を検 出する手法として, YUV 表色系へ変換して, 各画素の色 差比 $\mathrm{U} / \mathrm{V}$ のヒストグラムより閾值を求め 2 值化した眼球 画像と輝度画像による 2 值化画像と合成して求める手法 ${ }^{(6)}$ があるが，この手法は虹彩と目頭を検出するための手法で あり, 虹彩のみを検出する手法とは異なる。また, カラー コンタクトレンズを目に装着する手法 ${ }^{(10)}$ が提案されてい るが，この手法ではユーザにカラーコンタクトレンズの装 着という負担をかけてしまい, 特に普段コンタクトレンズ を装着しないユーザにとっては装着時の違和感があると考 
えられる。虹彩検出の高速化の研究としては, 外部カメラ で撮影した目画像から顔領域，目領域の抽出を行い，虹彩 の輪郭を Hough 変換を用いて抽出する方法 ${ }^{(11)}$ が提案され ている。エッジの特徵点数を減らした画像に対する Hough 変換を用いているが，特徵点数によっては依然として計算 時間の問題があると考えられる。視線インタフェースの構 築では，システム全体としての利用しやすさや精度を考慮 する必要があると考えられ，検出精度や処理スピード等の バランスが重要と考えられる。従って, 検出精度のみの向 上を目指すのは得策ではないと考えられる。そのため本論 文では，その形が単純な円形のパターンマッチングを採用 する。視線入力システムにおいては，今後装置の小型化が 望まれると考えられ，妥当な精度で高速に虹彩中心を求め る手法の提案はひいては小型化につながる。

本論文は視線入力インタフェースシステムを構築するた めの虹彩中心検出アルゴリズムとパターンマッチングの高 速化手法について取り扱ったものである。まず，目のカラー 画像を用いて, 虹彩を切り出す手法を提案する。明度画像 と彩度画像にそれぞれ個別に䦨值を設定して虹彩を切り出 すことにより，虹彩の検出が容易になることを示す。次に， 虹彩輪郭へ円をあてはめるパターンマッチングによる虹彩 中心検出手法について述べる。更に, 視線入力インタフェー スへの応用では，虹彩中心検出の処理時間を短縮し，実時 間処理を行うことが重要であることから，パターンマッチ ングの高速化のための 2 つの手法を提案し，その有効性を 示す。最後に, 頭部固定の状態で, ディスプレイ上の 25 点 の指標を注視したときの虹彩中心検出精度の推定結果につ いて報告する。

\section{2. 虹彩中心検出実験システム}

視線入力インタフェースシステムとして完成したときの ユーザとしては頭部や手足の動作が困難な障害者や健常者 である。健常者が使用する場合には頭部の動きが小さいと いう条件の下での使用を考えている。使用環境は室内とす る。図 1 にヘルメットに取り付けた小型ビデオカメラ装置 の様子を示す。実験は研究室内で行っており, 照明は室内 の天井灯のみである。小型ビデオカメラ（共立電子産業社 製 JPP-CM25F）は $1 / 3$ インチカラーC-MOS で 25 万 画素を有する。

実験を行うためのコンピュータの環境として，画像入力 ボード（imagenation 社製 PXC200）が装着された Win-

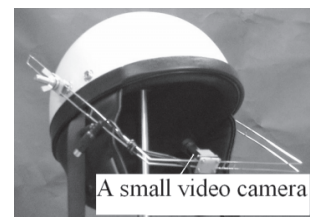

図 1 小型ビデオカメラのヘルメットへの装着

Fig. 1. The attachment of the video camera to the helmet. dows パソコン (CPU: PentiumIII 850MHz, MEMORY: 256MB, OS: Windows98SE) と, より高速の処理を行 うことができる虹彩中心検出用のワークステーション (CPU: XEON2.4GHz, MEMORY: 1GB, OS: RedHat Linux7.1)を個別に用意した。実験では, 動画像をフレー ム単位で処理するために, 画像入力用パソコンを用いてフ レーム単位の目画像を一旦ハードディスクに取り达んだ。 取り込んだ目画像をワークステーションに転送し，ハード ディスクに取り込み，虹彩中心検出処理の実験を行った。 な拀，後に述べる高速化手法の効果の検証をより効率的に 行うためにワークステーションを導入しているが，視線入 カインタフェースを実現する際には, 1 台のパソコン上で システムを構築する。

\section{3. 虹彩中心検出処理}

図 2 に虹彩中心検出アルゴリズムの処理の流れを示す。 処理は彩度画像と明度画像を用いたフィルタリングによる 虹彩の切り出しと円形パターンマッチングである。

虹彩中心検出は円形パターンマッチング処理により行う が, 円形パターンマッチングの対象として瞳孔輪郭あるい は虹彩輪郭が考えられる。ここでは, 検出が容易, 大きさ が常に一定，検出対象が大きいので映り込みの影響を緩和 できるという理由により虹彩輪郭外周部をマッチングの対 象とする。

以下，各処理手順について述べる。

〈3・1 色空間フィルタリング 虹彩と強膜の輪郭を 抽出して, 虹彩を切り出す手法として, 人間の知覚した色 を表示する方法の一つである $H S I$ 表色系を用いた。これ は $R, G, B$ の各画像を以下の $(1) \sim(5)$ 式で変換するもの である ${ }^{(12)}$ 。

各 $R, G, B$ の成分が 256 レベルで表現されているとき (3) (5) 式を用いて, 色相 $H$ (Hue), 彩度 $S$ (Saturation), 明度 $I$ (Intensity) を定義する。ここで, $\min (r, g, b)$ は $r$, $g$ ，および $b$ のうち最小の值のものを採用することを意味す る。また, $R=G=B$ の場合 $H=0$ とする。(6) (9) 式は, $S, I$ 值に㧈ける虹彩領域と他の領域 (肌領域, 強膜領域) との境界をより明確にするために $, r, g, b$ 值をシフトす るために導入した式である。

\begin{tabular}{|c|}
\hline Filtering in the HSI space \\
\hline $\begin{array}{l}\text { Preprocessing for pattern matching } \\
\text { - Reduction of processing area } \\
\text { - Edge detection in the processing area } \\
\text { - Detection of the centroid }\end{array}$ \\
\hline $\begin{array}{l}\text { Detection of the center of the iris } \\
\text { using pattern matching }\end{array}$ \\
\hline
\end{tabular}

図 2 虹彩中心検出アルゴリズム

Fig. 2. An algorithm for detecting the center of the iris. 


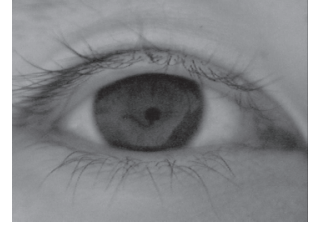

(a) An eye image $(640 \times 480)$

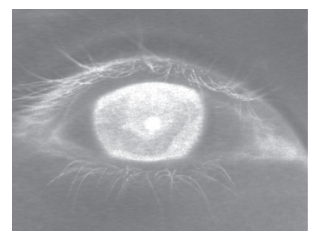

(c) The $S$ image

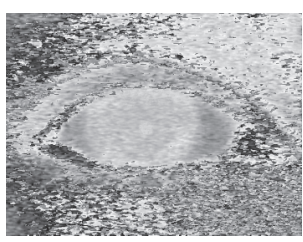

(b) The $H$ image

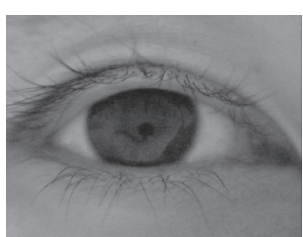

(d) The $I$ image
図 3 目画像と $H S I$ 画像

Fig. 3. An eye image and its $H S I$ images.

$$
r=\frac{R}{255}, \quad g=\frac{G}{255}, \quad b=\frac{B}{255}
$$

$\operatorname{Min}=\min (r, g, b)$

$H=\tan ^{-1} \frac{\sqrt{3}(g-b)}{(r-g)+(r-b)}$

$I=\frac{r+g+b}{3}$

$$
S=1-\frac{M i n}{I}
$$

$r_{s}=r+S_{r}, g_{s}=g+S_{g}, b_{s}=b+S_{b}$

$\operatorname{Min}_{s}=\min \left(r_{s}, g_{s}, b_{s}\right)$

$I_{s}=\frac{r_{s}+g_{s}+b_{s}}{3}$

$S_{s}=1-\frac{M_{i n}}{I_{s}}$

図 3(a)〜 (d) に室内光の下で撮影した目画像の原画像例, $H$ (色相) 画像, $S$ (彩度) 画像， $I$ (明度) 画像をそれぞ れ示す。

$H$ 画像では虹彩, 肌, 強膜の区別がつかないが，彩度画 像と明度画像では区別がつき，閾值を設定することにより 虹彩を抽出できることを示唆している。そこで，閾值処理 により虹彩領域の抽出が可能であるかを確認するため，虹 彩, 肌, 強膜の各領域に属する画素が $S-I$ 空間上のどの部 分を占めているかを調べた。

図 4(a) は目の原画像を虹彩，肌，強膜の各領域に手作業 で分割した図であり，それぞれの領域に属する画素を $S-I$ グラフ上に示したものを図 4(b)〜 (e) に示す。図 4(b) に示 すように，明度のみ，彩度のみ，あるいは明度と彩度に閾 值を設定して虹彩を切り出すことが考えられるが，虹彩部 と他の領域の境界が明確でないこともあり，闇值の設定が 難しい。そこで, 虹彩領域と他の領域との境界をより明確 にするために，(6)〜 (9) 式を導入した。これらの式におい て $r, g, b$ 值を $S_{r}, S_{g}, S_{b}$ を用いてシフトさせることに

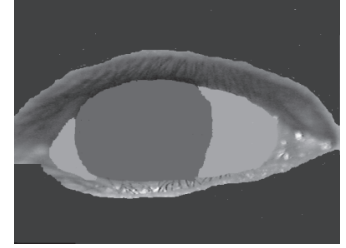

(a) The image devided into 3 regions

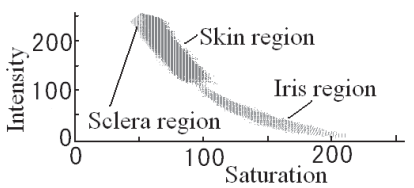

(c) The distribution of 3 regions in the $S-I$ plane using Eqs. (4) and (9) $\left(S_{r}=1, S_{g}=0, S_{b}=0\right)$

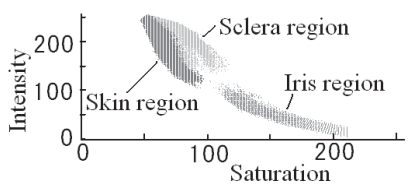

(e) The distribution of 3 regions in the $S-I$ plane using Eqs. (4) and (9) $\left(S_{r}=0, S_{g}=0, S_{b}=1\right)$

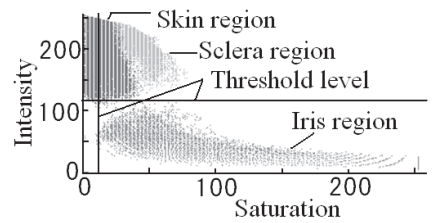

(b) The distribution of 3 regions in the $S-I$ plane using Eqs. (4) and (5)

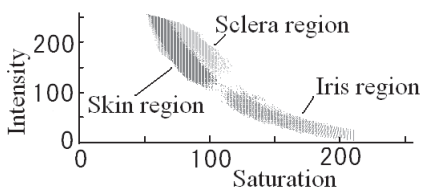

(d) The distribution of 3 regions in the $S-I$ plane using Eqs. (4) and (9) $\left(S_{r}=0, S_{g}=1, S_{b}=0\right)$

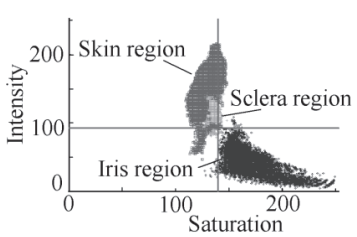

(f) The distribution of 3 regions of Fig. 3 (a) in the $S-I$ plane using Eqs. (4) and $(9)\left(S_{r}=0\right.$, $\left.S_{g}=0, S_{b}=1\right)$

図 4 領域分割と $S-I$ グラフ

Fig. 4. Segmentation of an eye image and its $S-I$ graphs.

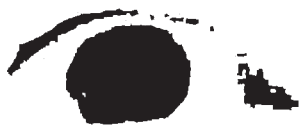

(a) Processed image created by filtering in the $H S I$ color space
困 5 虹彩検出

Fig. 5. Iris detection.

より虹彩と他の領域の $S$ 值の境界を明確にすることができ る。(6) 式の $S_{r}, S_{g}, S_{b}$ のいずれかの值を 1 に, 他の值 を 0 としたときの $S-I$ グラフを図 $4(\mathrm{c})$ 〜 (e) に示す。これ らの図より $S_{r}=S_{g}=0, S_{b}=1$ としたときに虹彩領域と他の 領域の境界がより明確になることが分かる。これらの実験 結果を踏まえ， $I, S$ をそれぞれ (4), (9) 式で求めた $S-I$ グラフを虹彩の切り出しに利用した。

図 4(f) には，図 4(a) とは被験者と照明条件が異なる例 も示すが， $S-I$ 空間上でそれぞれ閾值を設けることで，虹 彩部分の切り出しが可能になることを示唆しており, この 場合彩度 140 , 明度 92 を閾值として虹彩部を切り出すと, 図 5(a)に示す結果となる。なお, 図では切り出し後に 2 值 化した画像を示している。睫毛, 目頭, 目尻の一部も切り 出されているが, 虹彩部が切り出されていることが分かる。 このように, $S-I$ 空間上で閾值を設定して虹彩を切り出し 


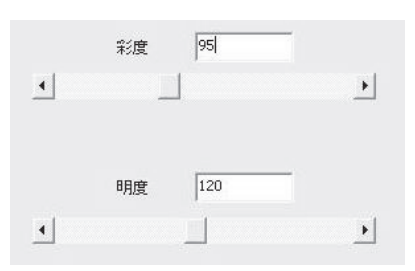

(a) The window to set the threshold values for $S$ and $I$

\section{ヒㅈドラムの咸値}

(b) The window to set the threshold value for the histogram in the vertical direction

図 6 閾值設定ウインドウ

Fig. 6. The windows to set the threshold values.

ていることから，ここではこの処理を色空間フィルタリン グと呼ぶ。

切り出しの閾值は照明条件や被験者によって変化するた め, すべての条件について有効な固定の閾值を設定するこ とは困難である。そのため, 視線検出実験の開始時に間值 の設定ができる閾值設定ウインドウを設けて対処している。 図 6(a) にウィンドウ画面を示す。設定した閾值に対して切 り出される虹彩画像を即座にウィンドウ上で確認できる機 能を実現しており，画像を確認しながら適切な閾值を設定 できるように配慮している。

〈3・2〉 パターンマッチングの前処理 〈3・1 節の処理 で切り出した 2 值画像中には虹彩以外の睫毛，目頭，目尻 などが含まれる。ここではこれらをノイズとして取り扱う。 ノイズ部を低減するために， $x$ (水平) 軸上への周辺分布を 計算して，閾值処理を行い虹彩のみを切り出した。

ここでの閾值は, 図 6(b) に示すように, 閾值設定ウィン ドウ上で設定した間值により切り出された虹彩画像を画面 上で見ながら適切な閾值に調整することができる。閾值は 0.6 0.7 程度である。周辺分布の閾值処理により切り出し た虹彩画像を図 $5(\mathrm{~b})$ に示す。虹彩と同幅の睫毛が残されて いるが，この画像に対して虹彩の輪郭抽出処理を行う。

虹彩輪郭抽出のためには水平方向，垂直方向の輪郭抽出 処理が考えられるが，ここでは水平方向のみの輪郭抽出処 理を行う。

〈3·3〉 パターンマッチング 〈3・2〉節の処理で求めた 虹彩輪郭に対してパターンマッチングを行い虹彩中心を求 める。重心を虹彩中心として用いる手法も考えられるが，虹 彩輪郭以外の領域の画素の影響を受けやすく，視線検出精 度の向上の点から考えると適切ではない。ここでの検出で は，正面を向いた 1 フレームの目画像から切り出された虹 彩の最大幅の画素数を求め，これを直径とする円を虹彩輪 郭にあてはめる基準円として採用し，以降のフレームでは その基準円を用いてパターンマッチングを行う。

図 7 に基準円を示す。虹彩内の「・」の位置が重心, 「十」 の位置が検出した虹彩中心,「・」を囲む四角形が基準円の 中心が移動する範囲である。また，基準円の内側の円（内 円）と外側の円（外円）で，はさまれた領域が環状領域と なる。環状領域を決定する 2 つ円の半径は（10）式およ

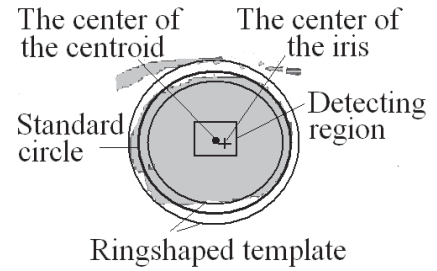

四 7 パターンマッチング

Fig. 7. Pattern matching.

び（11）式によって決めた。日本人成人男性 3 名の被験者 に対して係数 $a$ を決定するための実験を行った結果， 0.15 としたときに，良好な結果が得られたので，その值を採用 している。ここで $\rho$ は基準円の半径， $\rho_{i}$ は内円の半径， $\rho_{o}$ は外円の半径， $a$ は環状領域を決めるための係数である。

$$
\begin{aligned}
\rho_{i} & =\rho-a \rho[\text { pixel }] \\
\rho_{o} & =\rho+a \rho[\text { pixel }]
\end{aligned}
$$

1 フレーム目で基準円が決定されると, 以降のフレーム では環状領域内に存在する虹彩輪郭画素と基準円との距離 の差の 2 乗和を求め, その值が最小となるときの基準円の 中心を虹彩中心として扱うパターンマッチングを行ってい る。先に述べたように, 虹彩の外周部の形状は, 瞳孔に比 べて変化せず，安定しているので半径を固定したマッチン グで対処している。

\section{4. パターンマッチング高速化手法}

基準円の決定後, 目画像の各フレームに対してパターン マッチングを行うことで虹彩中心の検出が可能になる。全 体の処理時間に対するパターンマッチングの処理時間の割 合は，画像サイズで異なり $640 \times 480$ で約 $87 \%, 320 \times$ 240 で約 $55 \%$ ，160× 120 で約 $15 \%$ である。高解像度の 画像になるほどパターンマッチングの占める割合が大きく なる傾向がある。実時間処理を実現するためには, 高速な パターンマッチングの実現が望まれる。ここでは，パター ンマッチングの高速化を図るための 2 つの手法を提案する。

$\langle\mathbf{4} \cdot \mathbf{1}\rangle$ 中心候補点予測手法 1 つ目のパターンマッチ ングの高速化手法として虹彩重心位置から虹彩の中心位置 を予測する手法（ここでは中心候補点予測手法と呼ぶ）を 提案する。図 7 に示す手法では, パターンマッチングのた めの正方形の探査領域を虹彩重心の周囲に広範に渡って設 定しないと正しい虹彩中心位置が求まらない問題点があつ た。また，探査領域が広がることにより計算量も増えてい た。虹彩重心位置と虹彩中心位置との間に関係が見いださ れれば，その関係を中心位置予測に利用でき，探査領域を 絞り込むことにより計算量の削減が期待できる。ここでは 両者の関係を実験データにより定量的に評価し，予測に利 用できるかどうかを検討した。虹彩中心検出の実験の結果， 虹彩中心位置は虹彩の重心の近傍に存在することが分かっ た。視線を様々な方向に向けたときの目画像約 200 フレー 


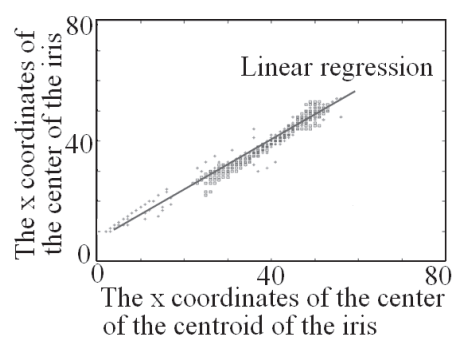

図 8 虹彩重心と虹彩中心の分布

Fig. 8. Relationship between the centroid of the iris and the center of the iris.

ムの画像から検出した虹彩重心位置の $x$ 座標と, 虹彩中心 位置の $x$ 座標の分布をプロットした結果を図 8 に示す。こ の図から虹彩中心と虹彩重心には相関があり, 回帰直線を 用いて虹彩重心位置から虹彩中心位置を予測できることが 分かる。提案手法によると重心位置から虹彩中心位置を予 測することができるので，円の中心探査領域を予測された 中心位置に絞り込んで設定しても良好なマッチング結果が 得られた。探査領域のサイズは実験的に求めた結果，640 $\times 480$ のサイズの目画像で $70 \times 70$ 画素の大きさから 30 $\times 30$ に低減できた。この予測による時間短縮の効果につ いては後の図 11 で示す。

$\langle\mathbf{4} \cdot \mathbf{2}\rangle$ 階層的走査法 〈3・3 節で導入した環状領域は 領域外の画素をパターンマッチングの対象から除外し, 虹 彩輪郭が含まれるであろうと考えられる領域内部のみをパ ターンマッチングの対象とするものである。環状領域は，パ ターンマッチングにおけるノイズ低減の効果を狙ったもの であるが，環状領域を走査したときの位置と，そこに含ま れる虹彩輪郭画素数との間に関係が見いだされれば，その 関係を利用した計算量の削減が期待できる。図 9 は $640 \times$ 480 の画像サイズの目画像に対して，虹彩中心の周囲に 40 $\times 40$ 画素の領域を設定し，基準円の中心位置を領域内で 順次走査したときの環状領域内の虹彩輪郭画素数を示した ものである。図では，その数を $z$ 軸に，基準円の中心位置 を $x-y$ 軸として関係を示している。

目の画像はあらゆる方向を見たときの画像約 4000 フレー ムを用いており，環状領域内の虹彩輪郭画素数の平均值を $z$ 軸に示している。環状領域内の虹彩輪郭画素数が虹彩中 心近傍で最大になり，周辺になると減少する単峰性の分布 を持つことがこの図から確認できる。この結果より図 10 に 示すように, Coarse to Fine の考え方を用いて，低解像度 と高解像度での階層的な走査による, パターンマッチング の効率化が期待できる。

すなわち，図に示すように，基準円の探査領域をメッシュ 状に分割して，その格子点上での環状領域内の虹彩輪郭画 素数をカウントし, その值が最大となる格子点位置を求め る。次に, その周囲に, 新たな格子点を設けて画素数をカ ウントするという手法を再帰的に適用することで探査領域 を絞り込む。絞り込まれた領域内でパターンマッチングを

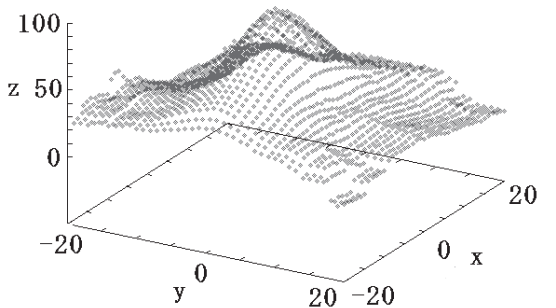

困 9 環状領域内での虹彩輪郭画素数の分布

Fig. 9. Distribution of the number of pixels of the iris contour within the ringshaped area.

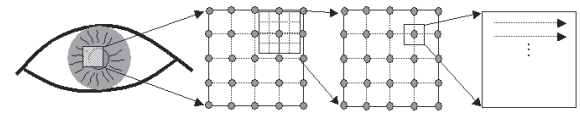

図 10 階層的走査法

Fig. 10. The coarse-to-fine scanning procedure.

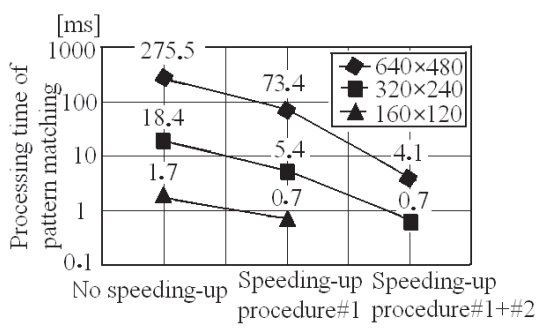

図 11 パターンマッチング処理時間

Fig. 11. Processing time of pattern matching.

行うことにより, 最終的に虹彩中心位置が求められる。図 11 に提案する 2 つの手法を用いた際のパターンマッチング 処理時間短縮の効果を示す。高速化なしは図 7 で示した手 法を示しており，高速化 1 が中心候補点予測手法を用いた 場合, 高速化 $1+2$ が更に階層的走査法を併用した場合に それぞれ対応している。高速化手法 1 を導入することで約 $1 / 4$ から $1 / 2$ の時間に短縮されていることが分かる。また, 高速化 2 も併用することで, 更に, 時間の短縮の効果が大 きいことが分かる。

\section{5. 検出精度と考察}

視線入力インタフェースシステムの実現に向けて目画像の 入力から視線方向推定までを 1 台のパソコンを用いて実現し, 注視点の検出精度を求める予備的な実験を行った。パソコン は Windows パソコン (CPU: Pentium4 3.2GHz, MEMORY: 1GB, OS: WindowsXP) である。小型ビデオカメラ, 画像入力ボードは虹彩中心検出実験システムと同じものを 用いた。小型ビデオカメラは，アルミ板に取り付け，アル ミ板はレンズを外したゴーグルに取り付けられている。取 り付けた様子を図 $12(\mathrm{a})$ に示す。実験は室内で行い, 照明 は天井の $100 \mathrm{~W}$ の電球と, 図 12(b) に示すようにディスプ レイ上部に $20 \mathrm{~W}$ の蛍光灯スタンドを用いた。照度は目の近 傍で 340lx 程度である。被験者はカメラを取り付けたゴー 


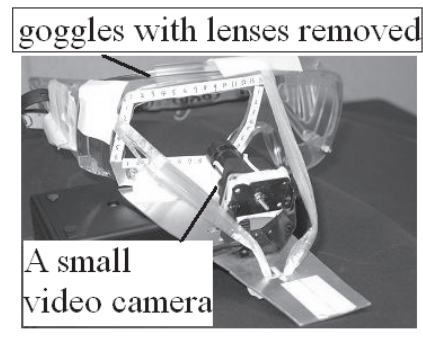

(a) Goggles with a video camera attached

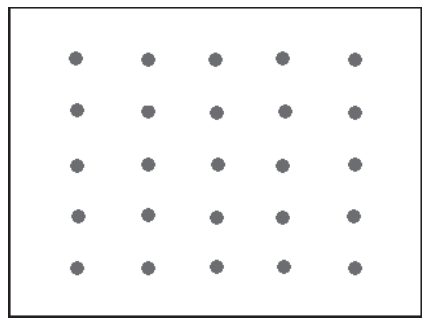

(c) 25 target points on the display

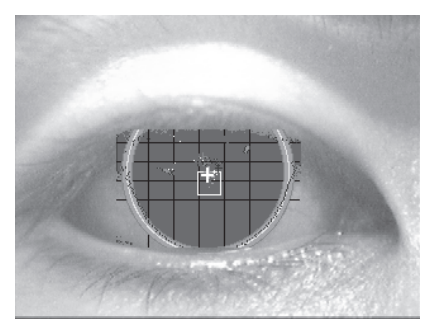

(e) An example of correct pattern matching

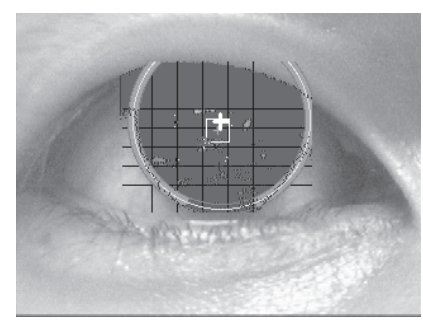

(g) An example of correct pattern matching

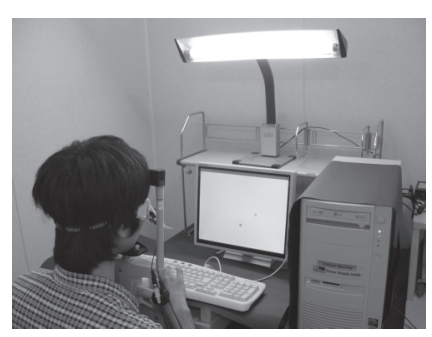

(b) Environment of accuracy evaluation experiment

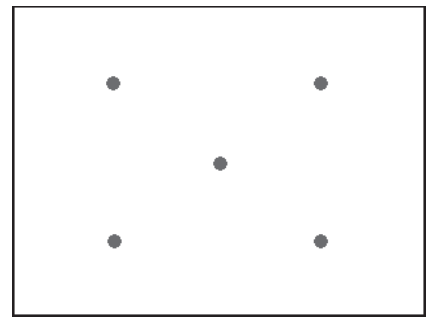

(d) 5 calibration target points on the display

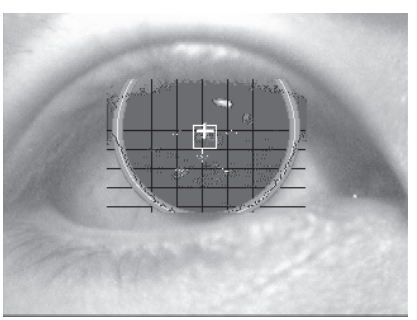

(f) An example of correct pattern matching

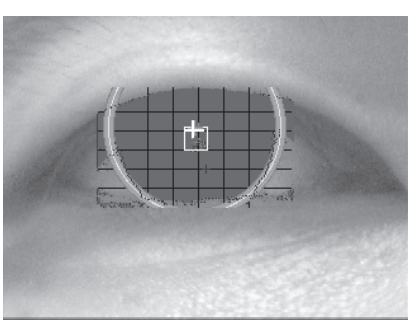

(h) An example of correct pattern matching

困 12 注視点検出実験

Fig. 12. Experiments on the accuracy of the eye gaze.

グルを頭部に装着して，顎のせ台と額あてにより頭部を固 定した。被験者の前方 $60 \mathrm{~cm}$ の位置に 17 インチのディスプ レイを配置し, その画面 (解像度 $1024 \times 768$ 画素) 上に直 径 30 画素の 25 個の赤色の円形の指標を困 $12(\mathrm{c})$ に示すよ うに配置した。ディスプレイ上の指標を 1 個ずつランダム に表示し，各指標を 2 秒間注視したときの目画像から注視 点の検出精度の評価を行った。被験者は日本人成人男性 5 名である。なお，推定されたディスプレイ上の位置は，画面 上には表示しないようにした。表示した場合には，被験者 が意図的に指標とのずれを補正する可能性があるので，今 回はその影響を除くため表示しないことにした。

目画像の虹彩中心位置と画面位置との対応関係を求める 校正に用いる指標は図 $12(\mathrm{~d})$ に示すように，ディスプレイ

表 1 検出誤差の平均值

Table 1. The mean value of detected error.

\begin{tabular}{|c|c|c|}
\hline Subject & $\begin{array}{c}\text { Mean value in the } \\
\text { horizontal direction }\left[{ }^{\circ}\right]\end{array}$ & $\begin{array}{c}\text { Mean value in the } \\
\text { vertical direction }\left[{ }^{\circ}\right]\end{array}$ \\
\hline $\mathrm{A}$ & 1.29 & 1.81 \\
\hline $\mathrm{B}$ & 2.45 & 2.76 \\
\hline $\mathrm{C}$ & 2.43 & 1.38 \\
\hline $\mathrm{D}$ & 1.11 & 0.86 \\
\hline $\mathrm{E}$ & 1.62 & 2.27 \\
\hline Average & 1.78 & 1.82 \\
\hline
\end{tabular}

表 2 検出誤差の標準偏差

Table 2. The standard deviation of detected error.

\begin{tabular}{|c|c|c|}
\hline Subject & $\begin{array}{c}\text { Standard deviation in the } \\
\text { horizontal direction }{ }^{\circ}{ }^{\circ}\end{array}$ & $\begin{array}{c}\text { Standard deviation in the } \\
\left.\text { vertical direction }{ }^{\circ}\right]^{\circ}\end{array}$ \\
\hline $\mathrm{A}$ & 0.99 & 1.69 \\
\hline $\mathrm{B}$ & 2.10 & 1.97 \\
\hline $\mathrm{C}$ & 1.57 & 1.27 \\
\hline $\mathrm{D}$ & 1.46 & 0.99 \\
\hline $\mathrm{E}$ & 1.05 & 1.39 \\
\hline Average & 1.43 & 1.46 \\
\hline
\end{tabular}

上の直径 30 画素の 5 個の赤い円とした。中央の指標のみが 精度を計算する指標と共通である。校正は福島らが提案し た校正法を用いた ${ }^{(13)}$ 。目画像サイズは $320 \times 240$ 画素で, 虹彩の直径は個人によって異なるが 140 画素程度である。

虹彩輪郭に基準円がマッチングしている例を図 12(e)〜 (h) に示す。これらの目画像は, 被験者も注視している指標 も異なっているが，いずれも基準円が虹彩輪郭にマッチン グしている様子が分かる。図のように, 虹彩の一部が瞼に 隠れている状況でも，虹彩輪郭を正しく捉えている。「+」 の位置が虹彩中心位置である。5人の被験者が指標を注視 したときの目画像から注視点を推定し, 指標との検出誤差 を $x$ 軸方向, $y$ 軸方向についてそれぞれ計算し, 25 個の指 標に対して平均值を求めた結果を表 1 に示す。表 2 には $x$ 軸方向, $y$ 軸方向の検出誤差の標準偏差を示す。 $x$ 軸方向 の検出誤差の 5 人の平均值は 1.78 度, 標準偏差は 1.43 度, $y$ 軸方向はそれぞれ 1.82 度と 1.46 度であった。精度評価 のための指標設定の違いはあるが，平均誤差が 0.8 度から 1.2 度という報告がある ${ }^{(8)}$ 。同程度の誤差で計算されてい ることが分かる。

\section{6. むすび}

頭部や手の動作が困難な重度肢体不自由者や健常者が頭 部固定の状態で使用するための視線入力インタフェース装 置を開発する目的で目画像から虹彩中心を検出するアルゴ リズムとその高速化，および検出精度について述べた。

色空間フィルタリング処理の実験では, 彩度と明度の情報 を利用することで虹彩部の抽出が容易になることが分かっ た。パターンマッチングの高速化手法の実験では, 虹彩中 心候補点予測手法や階層的な走査法の有効性が実験データ で明らかとなり，高速化に効果的であることが確認できた。 提案手法を 1 台のパソコンで実現して行った予備的な精度 
確認実験では，ディスプレイ上の 25 個の指標に対する検 出誤差の平均值と標準偏差が得られ, 従来の研究と同程度 の精度が得られることが分かった。実用性の高い視線入力 インタフェースシステムの実現のためには，本論文で述べ た高速化の他, まばたきへの対応, 校正手法, ディスプレ イ上の指標の大きさや配置等種々の要素の検討および最適 化を図っていく必要がある。また，デイスプレイ中央部か ら離れた点を注視するような視線方向では睫毛や瞼の影響 を受けやすくなり, 虹彩中心位置の誤検出により, 視線位 置推定の誤差が大きくなる問題点がある。ディスプレイ上 で利用できる領域の拡大のためにも, 今後この影響による 誤差の軽減手法の検討を進めていく。

\section{謝 辞}

研究にあたって日頃熱心にご討論いただき，協力してい ただいた熊本大学大学院自然科学研究科の福島敏貢氏と城 戸大輔氏に，また，ディスプレイを用いた精度実験に協力 いただいた，同研究科西村仁志氏に感謝いたします。

(平成 19 年 3 月 19 日受付, 平成 19 年 9 月 3 日再受付)

\section{文献}

（1）高松鶴吉・太田 茂:「障害者の可能性を拡げるコンピュー夕」, 中 央法規 (1990)

(2) L. Young and D. Sheena: "METHODS \& DESIGNS:Survey of eye movement recording methods", Behav. Res. Methods \& Instrum., Vol.7 (5), pp.397-429 (1975)

（3）古賀一男:「眼球運動実験ミニ・ハンドブック」, pp.25-120, 労働 科学研究所出版部 (1998)

(4) K. Itoh, Y. Sudoh, and T. Ifukube: "Eye Gaze Communication System for People with Severe Physical Disabilities", IEICE Trans. on Information \& Systems, Vol.J83-D-I, No.5, pp.495-503 (2000-5) (in Japanese)

伊藤和幸·数藤康雄·伊福部達:「重度肢体不自由者向けの視線入力方 式コミュニケーション装置」, 信学論 D-I, J83-D-I, 5, pp.495-503 (2000-5)

(5) N. Kanou, M. Inoue, Y. Kobayashi, T. Kawamura, and K. Nakashima: "Detection of the eye-focused character on moving syllabary by Neural Networks for ALS patients", T. IEE Japan, Vol.122-C, No.5, pp.744-752 (2002-5) (in Japanese) 加納尚之 ·井上倫夫 · 小林康浩 · 川村尚生 · 中島健二 :「ALS 患者 のためのニューラルネットワークを用いた文字盤の移動による注視 文字の検出」, 電学論 C, 122-C, 5, pp.744-752 (2002)

(6) K. Abe, M. Ohyama, and S. Ohi: "An Eye-gaze Input System Based on Image Analysis under Natural Light", Technical Report of IEICE, PRMU2003-158, pp.43-48 (2003) (in Japanese)

阿部清彦・大山 実・大井尚一：「自然光下に抢ける画像解析を用 いた視線入力システム」, 信学技報, PRMU2003-158, pp.43-48 (2003)

(7) T. E. Hutchinson, K. P. White, JR, W. N. Martin, K. C. Reichert, and L. A. Frey: "Human-Computer Interaction Using Eye-Gaze Input", IEEE Trans. Syst., Man \& Cybern., Vol.19 (6), pp.1527-1534 (1989)

(8) T. Akira, F. Kishino, and Y. Kobayashi: "Pupil Extraction Processing and Gaze Point Detection System Allowing Head Movement", IEICE Trans. on Information \& Systems, Vol.J76-D-II, No.3, pp.636-646 (1993-3) (in Japanese)
伴野明・岸野文郎・小林幸雄：「曈孔の抽出処理と頭部の動きを許容す る視線検出装置の試作」, 信学論 D-II, J76-D-II, 3, pp.636-646 (1993-3)

（9）関 亮:「紫外·赤外線の目に対する作用効果と安全」, 照学誌, Vol.61, No.11, pp.636-641 (1977)

(10) N. Nishiuchi, H. Takada, and K. Kurihara: "A Study on NonContact Line-of-Sight Detection Using Color Contact Lens", Trans. of JSME, C, Vol.65, No.636, pp.282-288 (1999-8) (in Japanese)

西内信之・高田一・栗原謙三：「カラーコンタクトレンズを利用 した非接触視線検出法の研究」, 日本機械学会論文集 C, Vol.65, No.636, pp.282-288 (1999-8)

(11) H. Kashima, H. Hongo, K. Kato, and K. Yamamoto: "High Speed Iris Detection Method for Man-Machine Interface", IEEJ Trans. FM, Vol.123, No.4, pp.346-352 (2003) (in Japanese)

加島英樹·本郷仁志·加藤那人・山本和彦 :「マン・マシンインタ フェースのための高速な虹彩検出法の考察」, 電学論 $\mathrm{A}, \mathbf{1 2 3}, 4$, pp.346-352 (2003-4)

（12）富永昌治:「コンピュータビジョンに扔けるカラー情報の表現と解 析」, コンピュータビジョン一技術評論と将来展望一, pp.64-79, 新技術コミュニケーションズ (1998)

(13) S. Fukushima, T. Arai, D. Morikawa, H. Shimoda, and H. Yoshikawa: "Development of Eye-Sensing Head Mounted Display", T. SICE, Vol.35, No.6, pp.699-707 (1999) (in Japanese)

福島省吾·新井 豪・森川大輔・下田 宏·吉川榮和：「Eye-Sensing Head Mounted Display の開発」, 計測自動制御学会論文集, Vol.35, No.6, pp.699-707 (1999)

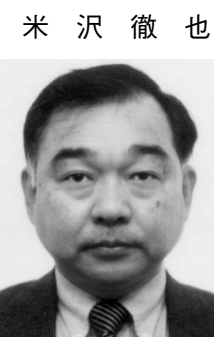

(正員) 1978 年, 大分大学工学部組織工学科卒 業。同年，八代高専情報電子工学科助手。1989 年, 同講師。1994 年, 同助教授。画像処理応用, ヒューマン・インタフェースに興味を持つ。正会 員。電子情報通信学会, 情報処理学会, 映像情報 メディア学会各会員。

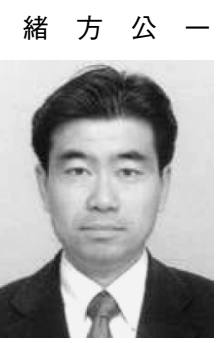

（正員） 1989 年, 熊本大学工学部電子工学科卒業。 1991 年, 同大大学院修士課程修了。1994 年, 同 大大学院博士課程修了。同年, 同大学助手。2002 年, 同大学助教授。博士 (工学)。音声科学, 画 像処理工学等の研究に従事。日本音響学会, 電子 情報通信学会各会員。

白 谷 和 幸 (非会員) 2003 年, 熊本大学工学部電気システ 厶工学科卒業。2005 年, 同大大学院自然科学研 究科博士前期課程修了。画像処理に関する研究に 従事。 